DOI: 10.12731/2227-930X-2020-3-157-164 УДК 656

\title{
О ПРАВОВЫХ НОРМАХ РЕГЛАМЕНТИРУЮЩИХ ОТВЕТСТВЕННОСТЬ ПЕРЕВОЗЧИКА ПРИ ПЕРЕВОЗКЕ ГРУЗА
}

\author{
Мельников А.Р., Мельникова М.А., \\ Мельникова И.П., Костюченко А. А.
}

В статье проанализированы основныле этапьл развития законодательно-правовой базы, касающейся ответственности перевозчика за вверенный ему грузовладельцем груз. Рассмотрен перечень конвенциональных документов, регламентирующих ограничение ответственности перевозчика за находящиися в его ведении груз.

Ключевые слова: конвенция; перевозчик; грузовладелец; ответственность перевозчика; коносамент; смешанная перевозка; Гаагские правила; Гамбургские правила; Гаагско-Висбийские правила; Роттердамские правила.

\section{ON THE LEGAL NORMS GOVERNING LIABILITY OF THE CARRIER IN THE CARRIAGE OF GOODS}

\author{
Melnikov A.R., Melnikova M.A., \\ Melnikova I.P., Kostyuchenko A.A.
}

The article analyses the main stages of the development of the legislative and legal framework concerning the liability of the carrier for the cargo entrusted to him by the owner. The list of conventional documents regulating the limitation of liability of the carrier for the goods under his control has been considered.

Keywords: convention; carrier; cargo owner; carrier liability; bill of lading; mixed carriage; Hague Rules; Hamburg Rules; Hague-Visby Rules; Rotterdam Rules. 


\section{Введение}

Отношения между участниками транспортного процесса и, главным образом, вопрос ответственности (и ее ограничения) перевозчика при организации международных морских перевозок грузов и перевозок грузов в смешанном сообщении регулируются правовыми нормами отдельных видов транспорта и Конвенцией $\mathrm{OOH}$ «О международных смешанных перевозках грузов» (заключена в г. Женеве 24.05.1980), (далее - Конвенция). Однако, в России, да и в целом в мире, Конвенция так и не вступила в силу (хотя на практике используется в качестве «факультативной нормы - необязательной к исполнению), что не лучшим образом отражается на взаимодействии в подсистеме «перевозчик - грузовладелец». Поэтому будет целесообразным рассмотреть вопросы ответственности морских перевозчиков за принятый к перевозке груз, как при морской перевозке, так и при участии морского транспорта, участвующего в смешанных перевозках.

\section{Материалы и методы исследования}

Методами исследования являлись общенаучные методы, в том числе изучение литературы, документов и результатов деятельности, экспертные оценки, анализ и синтез, обобщение, что позволило обеспечить достоверность исследования и обосновать его выводы.

\section{Результаты исследования и обсуждение}

Фундаментальный принцип, существовавший в течение нескольких веков в морских перевозках, заключался в том, что перевозчик нес абсолютную ответственность за утрату или порчу груза вне зависимости от причины утраты и независимо от того, проявлял ли он небрежность при перевозке или нет. Но к концу $\mathrm{XX}$ века морским перевозчикам удалось добиться снижения размера своей ответственности за перевозку грузов морем до такой степени, что это в конечном итоге стало неприемлемым для грузовладельцев. В августе 1924 г. в Брюсселе была принята «Меж- 
дународная Конвенция об унификации некоторых правил о коносаменте», так называемые Гаагские правила.

Гаагские правила стали определенным прогрессом в плане обеспечения единообразного толкования условий коносаментов и внесения ясности в режим ответственности перевозчика, распространяющейся на морские коносаменты. Это был важный шаг на пути к достижению всеобщего согласия в вопросе ответственности перевозчика за наносимый перевозимому морем грузу ущерб.

Гаагские правила были приняты большинством грузоотправителей и грузополучателей, однако судовладельцы выступили против расширения своей ответственности и правила были приняты вопреки их желанию. К примеру, против введения Гаагских правил приводился такой довод, что возросшая ответственность перевозчика приведет к увеличению страховых премий.

Более сорока лет Гаагские правила применялись в мировых морских перевозках, но развитие и рост объема контейнерных перевозок, увеличение размеров и, соответственно, стоимости судов, повышение доли перевозок, организуемых перевозчиком, который оформляет на перевозку сквозной транспортный документ, привело к необходимости внесения поправок в правила.

В 1967-1968 гг. на Брюссельской конференции был принят так называемый Висбийский протокол (вступил в силу в июне 1977 г. с уточнениями), содержащий «контейнерную оговорку». Эта оговорка дает возможность грузоотправителям требовать денежную компенсацию за каждое грузовое место, находящееся внутри контейнера или поддона, которое (отдельное грузовое место) фигурирует (выделено в тексте) в коносаменте.

Висбийский протокол совместно с Гаагскими правилами создали систему ответственности, которая общеизвестна как Гаагско-Висбийские правила. Россия присоединилась к Гаагско-Висбийским правилам в 1998 году.

В уточненном варианте Гаагско-Висбийские правила вошли в Гамбургские правила («Конвенция ООН о морской перевозке грузов»), принятые на Гамбургской конференции в 1978 г. [1, 2]. 
Согласно правилам:

- ответственность перевозчика определяется на основе принципа «презумпируемой вины»;

- какое-либо исключение не действует в случае вины перевозчика в части судовождения или управления судном;

- применятся сравнительно низкий предел ответственности (например, в отличие от Варшавской конвенции на авиатранспорте) в случае утраты груза или причинения ему ущерба;

- трудно выйти за низкий предел ответственности, исключение составляют те случаи, при которых «перевозчик сам совершает безответственные действия, зная, что они, возможно, повлекут за собой ущерб грузу, или действия с намерением причинить такой ущерб»;

- за палубный груз несет ответственность перевозчик;

- за задержку в сдаче груза несет ответственность перевозчик.

- возможное использование не только коносаментов, а и иных транспортных документов, например, морских накладных;

- с момента принятия груза в порту погрузки до момента его сдачи в порту выгрузки перевозчик несет ответственность за груз, т.е. ограничение «от поручня до поручня» расширено, а в настоящее время охватывается также портовая площадь;

- ответственность лежит и на фактическом перевозчике, а не только на перевозчике по договору.

Все отмеченное выше послужило более эффективному развитию перевозок грузов морем и взаимоотношений сторон транспортного процесса.

Гамбургские правила вступили в силу с 1 ноября 1992 г.

В тоже время основной объем перевозок в мире в настоящее время осуществляется в смешанном сообщении, когда в перевозке последовательно участвуют различные виды транспорта, доставляющие груз в рамках единой транспортной цепи, по единому транспортному документу, единой ставке и при единой ответственности организатора перевозки за доставку груза. Соответственно, вопрос организации процесса перевозки груза в смешанном сообщении по- 
требовал и соответствующего нормативного обеспечения. Вопрос сложный, требующий согласования правовых норм действующих на автомобильном, железнодорожном транспорте, таких как:

1. Конвенция о договоре международной дорожной перевозки грузов (КДПГ), Женева, 1956 г.

2. Конвенция о международных железнодорожных перевозках (CIM). (Добавление «В» к Конвенции о международных железнодорожных перевозках (COTIF) от 9 мая 1980 г.) [COTIF - Convention relative aux Transport international ferrowires.] [3,4].

\section{Заключение}

В заключение следует отметить, что в результате длительной работы морских юристов, специалистов-практиков, ученых, многочисленных согласований все-таки появилась правовая норма, позволяющая регулировать перевозку груза в смешанном сообщении: Конвенция ООН о договорах полностью или частично морской международной перевозки грузов (Нью-Йорк, 2008 год) (Роттердамские правила) [2].

Конвенция, где доминируют нормы принятые на морском транспорте, устанавливает единообразный правовой режим, регулирующий права и обязанности грузовладельцев и перевозчиков в соответствии с договором смешанной перевозки груза на условиях перевозки груза «от двери грузоотправителя до двери грузополучателя», которая включает этап международной морской перевозки. Конвенция основана на принятых ранее нормах, касающихся международной морской перевозки грузов, в частности на Гаагских правилах и протоколах к ним (Гаагско-Висбийские правила), а также на нормах Гамбургских правил, упомянутых нами выше.

Роттердамские правила обеспечивают правовую основу, которая учитывает технические и коммерческие изменения, произошедшие в секторе морских перевозок после принятия более ранних конвенций, включая расширение контейнерных перевозок, стремление к организации перевозок на условиях «от двери грузо- 
отправителя до двери грузополучателя» в рамках единого договора и развитие практики использования электронных транспортных документов. Конвенция предусматривает для грузоотправителей и перевозчиков имеющий обязательную силу сбалансированный универсальный режим, способствующий исполнению договоров морской перевозки грузов, которая может быть связана с использованием других видов транспорта. Нормы, заключенные в Роттердамских правилах, носят «факультативный характер», так как Конвенция до настоящего времени не ратифицирована требуемым числом государств.

\section{Список литературы}

1. Коммерческая работа на водном транспорте: конспект лекций / сост. А.Р. Мельников, Е.П. Сивак, Е.Ю. Юрченко, Е.А. Маркова. Владивосток: Мор. Гос. ун-т, 2010. 186 с.

2. Ответственность перевозчика при доставке груза одним видом транспорта и в смешанном сообщении / Мельников А.Р., Баранова Е.Ю., Новикова К.А. // Вестник Морского Государственного университета. 2011. № 49. С. 25-34.

3. Плужников К.И., Чунтомова Ю.А. Транспортное экспедирование. М.: ТРАНСЛИТ, 2006. $528 \mathrm{c.}$

4. The Economic and Commercial implications of the entry into force of the multimodal transport Convention. Report by the UNCTAD Secretariat. November 10. 1989. part 2. p. 8.

\section{References}

1. Commercial Work in Water Transport: Lecture Project/Stock. A.R. Melnikov, E.P. Siwak, E.Yu Yurchenko, E.A. Markova. Vladivostok: More. State. un-t, 2010. 186 p.

2. Liability of the carrier when delivering cargo by one mode of transport and in mixed communication / Melnikov A.R., Baranov E.Y., Novikova K.A.//Journal of the Maritime State University. 2011. № 49. P. 25-34.

3. Pluzhnikov K.I., Chuntomova Yu.A. Transport forwarding. M.: TRANSLIT, 2006. 528 p. 
4. The Economic and Commercial implications of the entry into force of the multimodal transport Convention. Report by the UNCTAD Secretariat. November 10. 1989. part 2. p. 8.

\section{ДАННЫЕ ОБ АВТОРАХ}

Мельников Александр Радиевич, к.т.н., профессор

Морской государственный университет им. адм. Г.И. Невельского

ул. Верхнепортовая 50-а, г. Владивосток, 690003, Россия melnikovar@msun.ru

Мельникова Марина Александровна, к.пс.н., доцент

Морской государственный университет им. адм. Г.И. Невельского

ул. Верхнепортовая 50-а, г. Владивосток, 690003, Россия ma_melnikova@mail.ru.

Мельникова Ирина Петровна, д.м.н., профессор

Морской государственный университет им. адм. Г.И. Невельского

ул. Верхнепортовая 50-а, г. Владивосток, 690003, Россия melira_6@mail.ru

Костюченко Алина Алексеевна, студентка

Морской государственный университет им. адм. Г.И. Невельского

ул. Верхнепортовая 50-а, г. Владивосток, 690003, Россия k_alina00@mail.ru

\section{DATA ABOUT THE AUTHORS}

Melnikova Irina Petrovna, Doctor of Medical Sciences, Professor Maritime state university of adm. G.I. Nevelskoy 50-a, Verkhneportovaya Str, Vladivostok, 690003, Russia melira_6@mail.ru

ORCID: 0000-0001-9071-6261 
Melnikov Alexander Radiyevich, candidate of Engineering Sciences, professor

Maritime state university of adm. G.I. Nevelskoy

50-a, Verkhneportovaya Str, Vladivostok, 690003, Russia

melnikovar@msun.ru

ORCID: 0000-0002-9066-7188

Melnikova Marina Aleksandrovna, candidate of Psychological Sciences, associate professor Maritime state university of adm. G.I. Nevelskoy 50-a, Verkhneportovaya Str, Vladivostok, 690003, Russia ma_melnikova@mail.ru

ORCID: 0000-0001-7546-3964

Kostyuchenko Alina Alekseevna, student

Maritime state university of adm. G.I. Nevelskoy

50-a, Verkhneportovaya Str, Vladivostok, 690003, Russia k_alina00@mail.ru

ORCID: 0000-0002-4497-5745 